\title{
PERAN GURU BIMBINGAN KONSELING DALAM MENGATASI TAWURAN PELAJAR
}

\author{
Eko Setiawan \\ Email: oke.setia@gmail.com \\ Korespodensi: Ds.Bangorejo Rt 04/Rw 03, Kec.Bangorejo, Kab Banyuwangi, 68487
}

\begin{abstract}
Brawl among adolescents currently emerging-proliferation. Brawl among students has been as commonplace among students Indonesia. Student brawls itself sometimes based on reasons that are not clear and unreasonable such as among schoolchildren taunted each other which eventually led to the brawl. The most surprising thing was when the arena fights made the event a show of force among students, which when students are won from the brawl, then regarded as a hero.
\end{abstract}

\section{Keywords: Guidance counseling, Fighting, Student}

PSIKOISLAMIKA. Jurnal Psikologi Islam (JPI) copyright @ 2015 Pusat Penelitan dan Layanan Psikologi. Volume 12. Nomor 2, Tahun 2015

\section{PENDAHULUAN}

Tawuran merupakan suatu perkelahian atau tindak kekerasan yang dilakukan oleh sekelompok atau suatu rumpun masyarakat. Kata tawuran sepertinya bagi masyarakat Indonesia ini sudah tidak asing lagi di telinga. Tawuran merupakan suatu kegiatan perkelahian atau tindak kekerasan yang dilakukan oleh sekelompok atau suatu rumpun masyarakat. Di Indonesia sendiri tawuran telah menjadi tradisi, atau bahkan budaya. Perilaku menyimpang ini biasanya diakibatkan oleh masalah sepele atau bisa saja disebabkan oleh hal-hal serius yang menjurus pada tindakan bentrok. Pada umumnya, tawuran diamati sebagai suatu tindakan yang tidak dibenarkan. Tawuran antar pelajar maupun tawuran antar remaja semakin menjadi semenjak terciptanya geng-geng sekelompok anak muda. Biasanya permusuhan antar sekolah itu terjadi dimulai dari masalah yang sangat sepele. Remaja yang masih labil tingkat emosinya justru menanggapi sebagai sebuah tantangan bagi mereka. Masalah sepele tersebut bisa berupa saling ejek ataupun masalah memperebutkan seorang wanita. Pemicu lain biasanya adanya rasa dendam. Dengan rasa kesetiakawanan yang tinggi para siswa tersebut akan membalas perlakuan yang disebabkan oleh siswa sekolah yang dianggap merugikan seorang siswa atau mencemarkan nama baik sekolah.
Tawuran pelajar beberapa waktu terakhir kembali mengemuka seolah menampar wajah banyak pihak. Puluhan pelajar mengalami lukaluka dalam tawuran yang terjadi di Jakarta pada Rabu, 26 September 2012. Data yang di ungkap Kompas (27 September 2012) menyebutkan, di Jakarta, dalam setahun ini korban tewas tawuran pelajar mencapai angka 13 orang dengan eskalasi yang semakin meningkat, baik dari sisi jumlah korban, maupun tingkat kerusakan. Tahun 2009 terjadi sebelas kali tawuran, tahun 2010 ada 28 kali dan tahun 2011 ada 31 kali tawuran. Dari data yang dilansir TV One, pada 2010 setidaknya terjadi 128 kasus tawuran antar pelajar diberbagai kota. Angka itu melonjak tajam lebih dari $100 \%$ pada 2011, yakni terjadi 330 kasus tawuran yang menewaskan 82 pelajar. Bahkan, pada JanuariJuli 2012 terjadi 139 tawuran yang menewaskan 12 pelajar (Asy'ari, 2012, h. 24 ). Hal inilah yang mengundang keprihatinan berbagai pihak sekaligus tantangan bagi kalangan agamawan, pemerintah, civitas akademika dan masyarakat pada umumnya untuk mencari solusi atas permasalahan tersebut (Bukhori, 2008, h. 6).

Remaja cenderung memiliki sifat agresi. Jika dipandang dari definisi emosional, pengertian agresi adalah hasil dari proses kemarahan yang memuncak. Sedangkan dari definisi motivasional perbuatan agresi 
adalah perbuatan yang bertujuan untuk menyakiti orang lain. Dari pengertian behavioral perbuatan agresi adalah sebagai respon dari perangsangan yang disampaikan oleh organisme lain (Willis, 2010, h. 121). Perilaku agresi berubah tingkat dan polanya pada masa remaja dan pada masa dewasa (Krahe, 2005, h. 80). Secara tradisional masa remaja dianggap sebagai periode "badai dan tekanan", suatu masa dimana ketegangan emosi meninggi sebagai akibat dari perubahan fisik dan kelenjar (Istiwidayanti, 1980, h. 212). Masa remaja dianggap sebagai masa topan-badai dan stress (storm and stress), karena mereka telah memiliki keinginan bebas untuk menentukan nasib diri sendiri. Kalau terarah dengan baik, maka ia akan menjadi individu yang memiliki rasa tanggung jawab, tetapi kalau tidak terbimbing, maka bisa menjadi seorang yang tidak memiliki masa depan yang baik (Dariyo, 2004, h. 13).

Masa remaja juga dikenal sebagai masa yang penuh kesukaran. Bukan saja kesukaran bagi individu yang bersangkutan tetapi juga bagi orang tuanya bahkan sering kali bagi polisi. Hal ini disebabkan masa remaja merupakan masa transisi antara masa kanak- kanak dan masa dewasa. Masa transisi ini seringkali menghadapkan individu yang bersangkutan kepada situasi yang membingungkan, disatu pihak ia masih kanak- kanak tetapi dilain pihak ia harus bertingkah laku seperti orang dewasa. Situasisituasi yang menimbulkan konflik seperti ini, sering menyebabkan perilaku yang aneh, canggung dan kalau tidak dikontrol bisa menjadi kenakalan remaja (Sarwono, 2010, h. 72).

Ada beberapa alasan yang mendorong penulis untuk memilih judul tersebut, diantaranya adalah: melihat kompleksnya permasalahan agresivitas remaja seperti yang telah di uraikan di atas, perlu kiranya usaha sungguh- sungguh untuk mengatasinya, karena remaja (siswa) adalah aset bangsa dan negara yang diharapkan dapat memberikan sumbangan positif bagi bangsa dan negara. Guru, orang tua, dan masyarakat tentu tidak mungkin hadir terus menerus untuk memantau atau membimbing para remaja setiap saat. Sebagai implikasi dari meningkatnya fenomena sosial dan psikologis tersebut, banyak pihak-pihak tertentu khususnya penulis, mempertanyakan faktor sebab-sebab terjadinya tawuran pelajar. Dan akhirnya berusaha mencoba menganalisis permasalahan psikologis yang muncul dan akhirnya merancang tindakan intervensi yang mungkin dapat dilakukan.

\section{Faktor Penyebab Tawuran Remaja}

Dalam pandangan psikologi, setiap perilaku merupakan interaksi antara kecenderungan dalam diri individu dan kondisi eksternal. Begitu pula dalam hal tawuran pelajar. Apabila dijabarkan, terdapat sedikitnya 4 faktor psikologis mengapa seorang remaja terlibat perkelahian pelajar, yaitu:

1. Faktor internal. Remaja yang terlibat perkelahian biasanya kurang mampu melakukan adaptasi pada situasi lingkungan yang kompleks. Kompleks di sini berarti adanya keanekaragaman pandangan, budaya, tingkat ekonomi, dan semua rangsang dari lingkungan yang makin lama makin beragam dan banyak. Situasi ini biasanya menimbulkan tekanan pada setiap orang. Tapi pada remaja yang terlibat perkelahian mereka kurang mampu untuk mengatasi, apalagi memanfaatkan situasi itu untuk pengembangan dirinya. Mereka biasanya mudah putus asa, cepat melarikan diri dari masalah, menyalahkan orang/pihak lain pada setiap masalahnya, dan memilih menggunakan cara singkat untuk memecahkan masalah. Pada remaja yang sering berkelahi ditemukan bahwa mereka mengalami konflik batin, mudah frustasi, memiliki emosi yang labil, tidak peka terhadap perasaan orang lain, dan memiliki perasaan rendah diri yang kuat. Mereka biasanya sangat membutuhkan pengakuan.

2. Faktor keluarga. Rumah tangga yang dipenuhi kekerasan (entah antar orang tua atau pada anaknya) jelas berdampak pada anak. Anak, ketika meningkat remaja, belajar melakukan kekerasan pula. Sebaliknya, orang tua yang terlalu melindungi anaknya ketika remaja akan tumbuh sebagai individu yang tidak mandiri dan tidak berani mengembangkan identitasnya yang unik. Begitu bergabung dengan temantemannya, akan menyerahkan dirinya secara total terhadap kelompoknya sebagai bagian dari indentitas yang dibangunnya. "Parenting yang sangat otoriter atau terlalu mengizinkan, antagonisme, penolakan dan komunikasi yang kurang baik di rumah berkaitan dengan tertariknya remaja kepada teman sebaya karena mereka berhubungan dengan konsep diri negatif remaja dan penyesuaian emosional yang kurang memadai".

3. Faktor sekolah. Sekolah pertama-tama bukan dipandang sebagai lembaga yang harus mendidik siswanya menjadi sesuatu. Tetapi sekolah terlebih dahulu harus dinilai dari kualitas pengajarannya. 
Karena itu, lingkungan sekolah yang tidak merangsang siswanya untuk belajar (misalnya suasana kelas yang monoton, peraturan yang tidak relevan dengan pengajaran, tidak adanya fasilitas praktikum, dsb), akan menyebabkan siswa lebih senang melakukan kegiatan di luar sekolah bersama teman-temannya. Baru setelah itu masalah pendidikan, di mana guru jelas memainkan peranan paling penting. Sayangnya guru lebih berperan sebagai penghukum dan pelaksana aturan, serta sebagai tokoh otoriter yang sebenarnya juga menggunakan cara kekerasan (walau dalam bentuk berbeda) dalam mendidik siswanya.

4. Faktor lingkungan. Lingkungan di antara rumah dan sekolah yang sehari-hari remaja alami, juga membawa dampak terhadap munculnya perkelahian. Misalnya lingkungan rumah yang sempit dan kumuh, dan anggota lingkungan yang berperilaku buruk (misalnya narkoba, tayangan kekerasan di TV yang hampir tiap hari disaksikan). Begitu pula sarana tranportasi umum yang sering menomor sekiankan pelajar. Juga lingkungan kota yang penuh kekerasan seperti yang kita saksikan di tayangan buser, sergap, patroli, dll. Semuanya itu dapat merangsang remaja untuk belajar sesuatu dari lingkungannya, dan kemudian reaksi emosional yang berkembang mendukung untuk munculnya perilaku berkelahi. Terutama untuk perbuatanperbuatan anti sosial dan kekerasan seperti yang sering ditayangkan di TV. Misalnya: film action yang penuh darah, WCW, UFC, PFC, Death Math, atau lebih nyata lagi seperti: Buser, Patroli, atau TKP. Yang semuanya itu sadar atau tidak bisa memicu tindak kekerasan pada remaja. Rasa solidaritas kelompok yang tinggi pada para pelajar SMU, bukan hanya terjadi ketika mereka senang, melainkan juga terjadi saat-saat duka, ada ancaman, kesulitan dan sebagainya.

\section{Dampak Tawuran Pelajar}

Para pelajar itu belajar bahwa kekerasan adalah cara yang paling efektif untuk memecahkan masalah mereka, karenanya memilih melakukan apa saja agar tujuannya tercapai. Perkelahian pelajar atau tawuran pelajar jelas merugikan banyak pihak. Paling tidak terdapat empat kategori dampak negatif dari perkelahian pelajar.

1. Pelajar dan keluarganya yang terlibat perkelahian mengalami dampak negatif pertama, bila mengalami cedera, cacat seumur hidup atau bahkan tewas.

2. Rusaknya fasilitas umum seperti taman kota, trotoar, bus, halte dan fasilitas lainnya serta fasilitas pribadi, seperti kendaraan, pecahnya kaca toko-toko.

3. Terganggunya proses belajar di sekolah.

4. Berkurangnya penghargaan siswa terhadap toleransi, perdamaian dan nilai-nilai hidup orang lain. Akibat yang terakhir ini memiliki konsekuensi jangka panjang terhadap kelangsungan hidup bermasyarakat di Indonesia.

5. Menurunnya moralitas para pelajar. Dari aspek fisik, tawuran dapat menyababkan kematian dan luka berat bagi para siswa. Kerusakan yang parah pada kendaraan dan kaca gedung atau rumah yang terkena lemparan batu. Sedangkan aspek mentalnya , tawuran dapat menyebabkan trauma pada para siswa yang menjadi korban, merusak mental para generasi muda, dan menurunkan kualitas pendidikan di Indonesia.

\section{Pendekatan Psikologis sebagai Alternatif untuk Mencegah Terjadinya Tawuran}

1. Harus dipahami bahwa tawuran merupakan perilaku yang tidak terpuji. Perilaku tawuran erat hubungannya dengan emosionalitas dan rasionalitas para pelajar, di mana saat tawuran, emosionalitas lebih berkuasa daripada rasionalitas. Oleh karena itu, solusi terbaik yaitu solusi yang berhubungan dengan substansi daripada emosionalitas-rasionalitas para pelajar. Artinya, perlu adanya pendekatan psikologis selama mereka berada di sekolah. Mereka harus mendapatkan pencerahan-pencerahan psikologis dari pihak yang kompeten dan mempunyai keahlian atau kompetensi di bidang itu.

2. Menanamkan kesadaran bahwa tawuran itu tidak ada segi positifnya. Menanamkan cara berpikir positif tentang bagaimana cara menyeleesaikan masalah secara baik-baik. Mengajari bagaimana caranya menghindarkan diri dari terjadinya tawuran. Memberitahu bagaimana caranya menyelamatkan diri dari bentrokan antar pelajar. Menanamkan faham bahwa mengalah bukanlah kalah. Mengajarkan bagaimana usaha untuk mengendalikan emosi negatif menjadi emosi positif.

3. Memberikan pendidikan etika dan moral untuk para pelajar. 
4. Menghadirkan seorang figur yang baik untuk dicontoh oleh para pelajar. Seperti hadirnya seorang guru, orangtua, dan teman sebaya yang dapat mengarahkan para pelajar untuk selalu bersikap baik.

5. Memberikan perhatian yang lebih untuk para remaja yang sejatinya sedang mencari jati diri.

6. Memfasilitasi para pelajar untuk baik dilingkungan rumah atau di lingkungan sekolah untuk melakukan kegiatan-kegiatan yang bermanfaat diwaktu luangnya. Contohnya: membentuk ikatan remaja masjid atau karangtaruna dan membuat acara-acara yang bermanfaat, mewajibkan setiap siswa mengikuti organisasi atau ekstrakulikuler disekolahnya.

7. Memberikan bentuk kegiatan dan pendidikan yang relevan dengan kebutuhan remaja zaman sekarang serta kaitannya dengan perkembangan bakat dan potensi remaja.

Selain orang tua dan sekolah, dalam hal ini polisi mempunyai peranan penting dalam menindak para pelaku tawuran pelajar. Peran aparat kepolisian dalam menindak para pelaku tawuran pelajar sangatlah penting. Aparat kepolisian yang mempunyai peran sebagai kontrol sosial harus bertindak dan bergerak cepat dalam menangani peristiwa tawuran pelajar sebelum menimbulkan kerugian yang besar baik materiil maupun formil. Peranan kepolisian tidaklah hanya sebagai pihak yang menghentikan tawuran pada saat terjadinya suatu tawuran, tetapi aparat kepolisian juga harus bertindak sebagai penegak keadilan dan penegak hukum terhadap para pelaku tawuran pelajar yang tertangkap. Pasal 30 ayat (4) Undang-Undang Dasar 1945 menyebutkan "Kepolisian Negara Republik Indonesia sebagai alat Negara yang menjaga keamanan dan ketertiban masyarakat bertugas melindungi, mengayomi, melayani masyarakat, serta menegakkan hukum".

Kewenangan kepolisan sebagai penegak hukum dalam hal bertindak memerlukan kecermatan dan ketelitian dalam mengungkap suatu tindak pidana. Penegakan hukum terhadap tindak pidana dengan kekerasan yang dilakukan oleh pelajar sekolah harus dijalankan sesuai dengan peraturan perundang-undangan yang berlaku, walaupun dalam kenyataannya Undang-undang yang mengatur tentang tawuran pelajar belum ada dan diatur secara khusus. Seringkali aparat kepolisian dalam menangani tindak pidana tawuran mengalami kendala dan masalah terhadap para pelaku tawuran pelajar. Dengan perkataan lain kesadaran hukum dan sikap tertib masyarakat untuk sebagian besar tergantung sejauh mana kewibawaan kepolisian. Semakin nyata kewibawaan itu semakin kuat kesadaran hukum dan tertib masyarakat. Semakin kabur kewibawaan kepolisan akan semakin lemah kesadaran hukum dan sikap tertib masyarakat (Tabah, 1996, h. 2).

Peran aparat kepolisian tidak hanya sebatas di lapangan saja dalam menangani dan mengamankan tawuran pelajar. Aparat kepolisian juga berperan dalam penangkapan dan penyidikan kepada pelaku tawuran pelajar. Penangkapan dilakukan di tempat kejadian kepada pelaku yang dianggap sebagai provokator. Penyidikan dilakukan untuk mengetahui motif tawuran, para pelaku dan kronologi tawuran pelajar yang dilakukan. Memanglah sulit membuat pertimbangan tindakan apa yang akan diambil dalam saat yang singkat pada penanggapan pertama suatu tindak pidana (Hamzah, 1993, h. 81).

\section{Pengawasan dan Peran Guru BK Dalam Mengatasi Tawuran Pelajar}

Tawuran sepertinya sudah menjadi bagian dari budaya bangsa Indonesia. Sehingga jika mendengar kata tawuran, sepertinya masyarakat Indonesia sudah tidak asing lagi. Tawuran antar pelajar maupun tawuran antar remaja semakin menjadi semenjak terciptanya geng-geng. Perilaku anarki selalu dipertontonkan di tengah-tengah masyarakat. Mereka itu sudah tidak merasa bahwa perbuatan itu sangat tidak terpuji dan bisa mengganggu ketenangan masyarakat. Sebaliknya mereka merasa bangga jika masyarakat itu takut dengan geng/kelompoknya. Seorang pelajar seharusnya tidak melakukan tindakan yang tidak terpuji seperti itu.

Setelah kita tahu akar permasalahannya, sekarang yang terpenting adalah bagaimana menemukan solusi yang tepat untuk menyelesaikan persoalan ini. Dalam hal ini, seluruh lapisan masyarakat yaitu, orang tua, guru/sekolah dan pemerintah. Pendidikan yang paling dasar dimulai dari rumah. Orang tua sendiri harus aktif menjaga emosi anak. Pola mendidik juga barangkali perlu dirubah. Orang tua seharusnya tidak mendikte anak, tetapi memberi keteladanan. Tidak mengekang anak dalam beraktifitas yang positif. Menghindari kekerasan dalam rumah tangga sehingga tercipta suasana rumah yang aman dan nyaman bagi tumbuh kembang si anak. Menanamkan dasar-dasar agama pada proses pendidikan. Tidak kalah penting adalah membatasi anak melihat kekerasan yang ditayangkan Televisi. 
Media ini memang paling jitu dalam proses pendidikan. Orang tua harus pandai-pandai memilih tontonan yang positif sehingga bisa menjadi tuntunan buat anak. Untuk membatasi tontonan untuk usia remaja memang lumayan sulit bagi orang tua.

Karena internetpun dapat diakses secara bebas dan orang tua tidak bisa membendung perkembangan sebuah teknologi. Filter yang baik buat anak adalah agama dengan agama si anak bisa membentengi dirinya sendiri dari pengaruh buruk apapun dan dari manapun. Dan pendidikan anak tidak seharusnya diserahkan seratus persen pada sekolah. Peranan sekolah juga sangat penting dalam penyelesaian masalah ini. Untuk meminimalkan tawuran antar pelajar, sekolah harus menerapkan aturan tata tertib yang lebih ketat, agar siswa tidak seenaknya keluyuran pada jam-jam pelajaran di luar sekolah. Yang kedua peran BK ( Bimbingan Konseling harus diaktifkan dalam rangka pembinaan mental siswa, membatu menemukan solusi bagi siswa yang mempunyai masalah sehingga persoalan-persoalan siswa yang tadinya dapat jadi pemicu sebuah tawuran dapat dicegah. Yang ketiga mengkondisikan suasana sekolah yang ramah dan penuh kasih sayang. Peran guru disekolah semestinya tidak hanya mengajar tetapi menggantikan peran orang tua mereka, yakni mendidik. Yang keempat, penyediaan fasilitas untuk menyalurkan energi siswa. Contohnya menyediakan program ektrakurikuler bagi siswa. Pada usia remaja energi mereka tinggi, sehingga perlu disalurkan lewat kegiatan yang positif sehingga tidak berubah menjadi agresivitas yang merugikan.

Dalam penyelenggaraan kegiatan ekstrakurikuler, ini sekolah membutuhkan prasarana dan sarana, seperti arena olahraga dan perlengkapan kesenian, yang sejauh ini di banyak sekolah belum memadai, malah cenderung kurang. Oleh karenanya, pemerintah perlu mensubsidi lebih banyak lagi fasilitas olahraga dan seni. Dari segi hukum demikian juga. Pemerintah harus tegas dalam menerapkan sanksi hukum. Berilah efek jerah pada siswa yang melakukan tawuran sehingga mereka akan berpikir seratus kali jika akan melakukan tawuran lagi. Karena bagaimanapun mereka adalah aset bangsa yang berharga dan harus terus dijaga untuk membangun bangsa ini.

Guru, orang tua, dan masyarakat tentu tidak mungkin hadir terus menerus untuk memantau atau membimbing para remaja setiap saat. Ada suatu kontrol yang dapat digunakan untuk menurunkan agresivitas, khususnya emosi remaja yang meledakledak, yakni dengan kontrol diri. Kontrol diri diartikan sebagai kemampuan untuk menyusun, membimbing, mengatur dan mengarahkan bentuk perilaku yang dapat membawa kearah konsekuensi positif. Kontrol diri merupakan salah satu potensi yang dapat dikembangkan dan digunakan individu selama proses-proses dalam kehidupan, termasuk dalam menghadapi kondisi yang terdapat dilingkungan sekitarnya (Risnawati, 2010, h. 21).

Adapun salah satu usaha untuk meningkatkan kontrol diri adalah dengan ber muraqabah kepada Allah. Istilah muraqabah diterapkan pada konsentrasi penuh waspada, dengan segenap jiwa, pikiran, dan imajinasi, serta pemeriksaan yang hamba mengawasi dirinya sendiri dengan cermat (Amstrong, 1996, h. 197). Sikap mental muraqabah adalah suatu sikap selalu memandang Allah dengan mata hatinya atau vision of the heart. Sebaliknya ia pun sadar bahwa Allah juga selalu memandang kepadanya dengan penuh perhatian (Jumantoro, 2005, h. 151).

Muraqabah dalam tradisi sufi adalah kondisi batin dimana orang memposisikan dirinya pada keadaan waspada dan konsentrasi penuh, sehingga segala pikiran dan perasaannya selalu terfokus pada kesadaran diri yang mantap. Muraqabah selanjutnya bermakna akan rasa penyatuan diri dengan Tuhan, dengan alam dan diri sendiri. Muraqabah adalah hal atau kondisi yang sangat penting, sebab segala kegiatan spiritual dan segala perilaku dan perbuatan pada hakikatnya ditujukan untuk pendekatan diri kepada Allah. Hal yang penting dalam muraqabah ini adalah sikap konsisten terhadap perilaku yang baik, atau perilaku yang seharusnya dilakukan (Nahrowi, 2012, h. 101).

\section{KESIMPULAN}

Ada empat faktor psikologis mengapa seorang remaja terlibat perkelahian pelajar, yaitu: faktor internal, keluarga, sekolah, lingkungan.

Dampak tawuran, dari aspek fisik, tawuran dapat menyababkan kematian dan luka berat bagi para siswa. Kerusakan yang parah pada kendaraan dan kaca gedung atau rumah yang terkena lemparan batu. Sedangkan aspek mentalnya , tawuran dapat menyebabkan trauma pada para siswa yang menjadi korban, merusak mental para generasi muda, dan menurunkan kualitas pendidikan di Indonesia.

Pendekatan psikologis sebagai alternatif untuk mencegah terjadinya tawuran, antara lain: harus dipahami bahwa tawuran merupakan perilaku yang tidak terpuji, menanamkan kesadaran bahwa tawuran itu tidak ada segi positifnya, memberikan pendidikan etika dan moral untuk para pelajar, 
memberikan bentuk kegiatan dan pendidikan yang relevan dengan kebutuhan remaja zaman sekarang serta kaitannya dengan perkembangan bakat dan potensi remaja. Selain orang tua dan sekolah, dalam hal ini polisi mempunyai peranan penting dalam menindak para pelaku tawuran pelajar.

Pengawasan dan peran guru BK dalam mengatasi tawuran pelajar, peran guru BK (Bimbingan Konseling) harus diaktifkan dalam rangka pembinaan mental siswa, membatu menemukan solusi bagi siswa yang mempunyai masalah sehingga persoalanpersoalan siswa yang tadinya dapat jadi pemicu sebuah tawuran dapat dicegah. Guru, orang tua, dan masyarakat tentu tidak mungkin hadir terus menerus untuk memantau atau membimbing para remaja setiap saat. Ada suatu kontrol yang dapat digunakan untuk menurunkan agresivitas, khususnya emosi remaja yang meledak-ledak, yakni dengan kontrol diri. Kontrol diri diartikan

\section{DAFTAR PUSTAKA}

Amstrong, Amatullah. 1996. Khazanah Istilah Sufi : Kunci Memasuki Dunia Tasawuf. Bandung : Mizan.

Asy'ari, Hasyim. "Tawuran Pelajar: Problem Tradisi, Karakter atau Kurikulum?"disampaikan dalam seminar loka karya yang diselenggarakan oleh Ma'had Qudsiyyah Kudus bekerja sama dengan Nurul Maiyyah Indonesia, Hotel Griptha, Kudus, 20 Oktober 2012.

Bukhori, Baidi. 2008. Zikir Al- Asma' Al-Husna Solusi Atas Problem Agresivitas Remaja. Semarang : Syiar Media Publishing.

Dariyo, Agoes. 2004. Psikologi Perkembangan Remaja. Bogor: Ghalia Indonesia.

Hamzah, Andi. 1993. Hukum Acara Pidana Indonesia. Jakarta: CV Sapta Artha Jaya.

Istiwidayanti. 1980. Psikologi Perkembangan Suatu Pendekatan Sepanjang Rentang Kehidupan. Jakarta : Erlangga. sebagai kemampuan untuk menyusun, membimbing, mengatur dan mengarahkan bentuk perilaku yang dapat membawa kearah konsekuensi positif. Salah satu usaha untuk meningkatkan kontrol diri adalah dengan ber muraqabah kepada Allah SWT.

\section{SARAN}

Singkatnya, solusi terbaik yaitu adanya program mengubah mindset para pelajar dari perilaku protawuran menjadi perilaku anti-tawuran. Perlu program latihan pengendalian emosi dan semacamnya. Untuk itu, dibutuhkan pencerahan-pencerahan psikologis yang langsung menyentuh kejiwaan para pelajar. Tentu, harus dilakukan oleh pihak yang mempunyai keahlian untuk itu.

Seluruh lapisan masyarakat harus ikut berperan dalam menanggulangi kasus tawuran pelajar, yaitu orang tua, guru/sekolah, pemerintah termasuk juga aparat kepolisian yang menangani para pelaku tawuran pelajar tersebut.

Jumantoro, Totok. 2005. Kamus Ilmu Tasawuf. Jakarta: Amzah.

Krahe, Barbara. 2005. Perilaku Agresi. Yogyakarta: Pustaka Pelajar.

Nahrowi, Moenir. 2012. Menjelajahi Eksistensi Tasawuf Meniti Jalan Menuju Tuhan. Jakarta: PT. As- Salam Sejahtera.

Risnawati, Ririn. 2010. Teori- Teori Psikologi. Jogjakarta: Ar- Ruzz Media.

Sarwono, Sarlito. 2010. Pengantar Psikologi Umum. Jakarta : PT Raja Grafindo Persada.

Tabah, Anton. 1996. Polisi, Budaya dan Politik. Klaten: CV. Sahabat.

Willis, Sofyan. 2010. Remaja \& Masalahnya, Mengupas Berbagai Bentuk Kenakalan Remaja Seperti Narkoba, Free seks dan Pemecahannya. Bandung : Alfabeta. 